\title{
Associations between Physical Activity and Liver Cancer Risks and Mortality: A Systematic Review and Meta-Analysis
}

\author{
Junga Lee \\ Sports Medicine and Science, Kyung Hee University, Global Campus 17104, Korea; jalee@khu.ac.kr
}

Received: 24 October 2020; Accepted: 27 November 2020; Published: 1 December 2020

\begin{abstract}
Background: The purpose of this meta-analysis was to investigate associations between physical activity (PA) and risks and mortality of liver cancer (LC) to suggest a minimum physical activity threshold to reduce LC risks and morality. (2) Methods: A database search was performed to identify relevant studies on the associations between PA and risks and mortality of LC before August 2020. The PA amounts were divided into three groups (high: $\geq 3 \mathrm{~h} /$ week, moderate: $2-3 \mathrm{~h} /$ week, and low: $<2 \mathrm{~h} /$ week). The pooled relative risks of LC were calculated. (3) Results: A total of 10 prospective cohort studies were included. LC risks and mortality were $26 \%$ and $25 \%$ lower with high amounts of PA and 23\% and 19\% lower in moderate amounts of PA, respectively, compared to low amounts of PA. At the vigorous intensity PA level, high and moderate amounts of PA reduced the LC risk by $54 \%$ and $45 \%$, respectively. (4) Conclusions: PA helps to reduce LC risks and mortality in a dose-dependent manner. At a minimum, two hours/week PA are mandatory to reduce LC mortality.
\end{abstract}

Keywords: lung cancer; physical activity; mortality; meta-analysis

\section{Introduction}

Liver cancer is the fourth leading cause of death worldwide and accounts for about 782,000 deaths in the global population [1]. The mortality of liver cancer has increased by about $65 \%$ in the last two decades, during which obesity, diabetes, and physical inactivity have increased [2]. The prognosis for liver cancer survival is worse than for other cancers; finding effective behaviors to prevent liver cancer will be important for patients [3,4]. Increasing physical activity may play a pivotal role in reducing the associated risks and mortality of liver cancer because of the beneficial effects of physical activity, which can reduce adiposity in the body, insulin levels, insulin resistance, and inflammation factors, which can improve lipid profiles [5-7].

Although several cancer studies including studies on breast cancer, colorectal cancer, lung cancer, prostate cancer, and ovarian cancer have reported inverse associations between physical activity and risks and mortality for all cancers, only a few studies have investigated these associations in liver cancer [8-11]. Additionally, the association between physical activity and cancer mortality had a dose-response with physical activity $[12,13]$ and those associations were dependent on physical activity intensity [14]. Regarding liver cancer, a previous meta-analysis reported an inverse association between daily total physical activity and risk of liver cancer in two studies, and did not find a significant association between leisure physical activity time and risks of liver cancer in five studies, which showed the associations between physical activity type, including daily total physical activity, leisure physical activity, and liver cancer risk [15]. Another previous meta-analysis demonstrated an inverse association between physical activity and risks of liver cancer in eight studies, which reported the associations between total physical activity and liver cancer risk regardless of physical activity amount, intensity, and type. Associations between liver cancer mortality and total physical activity were inversely 
associated in three studies [16]. The amount, intensity, and type of physical activity influenced liver cancer risk and mortality. To date, no meta-analysis has assessed the association between liver cancer risks and mortality and physical activity based on the dose-response of physical activity. Because the amount of physical activity can impact chronic disease factors, the association between liver cancer risks and mortality and the intensity of physical activity should be investigated. Therefore, the purpose of this meta-analysis was to investigate the associations between physical activity and liver cancer risks and mortality, depending on the amount of time and intensity of physical activity. In addition, determining benefits of physical activity, including the minimum amount of time and intensity of physical activity, can provide guidance for reducing liver cancer risks and mortality.

\section{Materials and Methods}

\subsection{Eligible Studies}

The Preferred Reporting Items for Systematic Reviews and Meta-analyses (PRISRM) system was used for this meta-analysis [17]. Eligible studies published in English from January 2007 to August 2020 were found using the PubMed and EMBASE databases. Several key terms used in the search to select relevant studies were: "liver cancer," "physical activity," "exercise," "risk of liver cancer," "liver cancer incidence," "liver cancer mortality," "liver cancer death," and "liver cancer survival". Possible combinations of these key terms were used to find all relevant studies. Cited references were reviewed to estimate any additional relevant studies. A researcher and a reviewer searched relevant studies independently based on inclusion and exclusion criteria. Any disagreements about selected studies between the researcher and reviewer were discussed to come to an agreement. All relevant studies followed our inclusion and exclusion criteria. Reporting the relative ratio (RR) or hazard ratio (HR) of associations between physical activity and risks and mortality of liver cancer, presenting physical activity assessments, criteria for cause of death, and being a prospective cohort study were required for inclusion. Reviewed studies, pilot studies, protocol studies, and studies without a RR or HR were excluded.

\subsection{Data Extraction}

The basic characteristics of selected studies, including the name of the first author, year of publication, the name of cohort studies, study design, country where the study was conducted, sample size, follow-up period, criteria for the risks and mortality of liver cancer, assessments of physical activity, RR or HR, 95\% CIs, and adjusted values for each study were extracted. All information from the studies is presented in Table 1, based on the guidelines for the Meta-analysis of Observational Studies in Epidemiology.

\subsection{Statistical Analysis}

A summary of the RR with 95\% confidence intervals (CI) across the selected studies was computed to find the associations between physical activity and risks and mortality of liver cancer. The amounts of physical activity were divided into three groups (high: $\geq 3 \mathrm{~h} /$ week, moderate: $2-3 \mathrm{~h} /$ week, and low: $<2 \mathrm{~h} /$ week). The averages of the three groups that were directly extracted from the selected studies were used as cut-off points. If the summary of the RR was a heterogeneous model $(p>0.1)$, a random-effects model was used. If the summary of the RR was homogenous $(p<0.1)$, a fixed-effects model was used. Heterogeneity across sampled studies was determined by using the $Q$ statistic. Inconsistency across the sampled studies was detected by using the $\mathrm{I}^{2}$ statistic. Publication bias was determined by using the Begg and Egger tests and a visual inspection of the funnel plot. All statistical analyses were conducted with a comprehensive meta-analysis version 1.25 software program (Biostatic, Inc., Englewood, NJ, USA). 
Table 1. Characteristics of selected studies: physical activity and liver cancer risks and mortality.

\begin{tabular}{|c|c|c|c|c|c|c|c|}
\hline $\begin{array}{l}\text { First Author (Year), Name } \\
\text { of Sudy, Country }\end{array}$ & $\begin{array}{c}\text { Sample Size } \\
\text { Study, } \\
\text { Recruitment } \\
\text { Period, and Age }\end{array}$ & $\begin{array}{l}\text { Follow-Up } \\
\text { Period (Year) }\end{array}$ & $\begin{array}{l}\text { Criteria of the } \\
\text { Cause of Death }\end{array}$ & $\begin{array}{c}\text { Exercise } \\
\text { Assessment }\end{array}$ & $\begin{array}{r}\text { Relative Rati } \\
\text { Exercise: Metabolic E } \\
\text { (MET)/Hou }\end{array}$ & $\begin{array}{l}\% \text { CI) } \\
\text { alent of Task } \\
\text { ek }\end{array}$ & Adjusted for \\
\hline $\begin{array}{l}\text { Arem (2017), } \\
\text { the NIH-AARP Diet and } \\
\text { Health study cohort, U.S.A. }\end{array}$ & $\begin{array}{l}566,398 \\
(1995-1997), \\
50-71 \text { years old }\end{array}$ & $\begin{array}{l}\text { Median: } \\
13.1 \text { years }\end{array}$ & $\begin{array}{l}\text { Hepatocellular carcinoma (HCC) } \\
\text { with morphology code, and cancer } \\
\text { registry case } \\
\text { ascertainment }\end{array}$ & $\begin{array}{l}\text { Physical activity } \\
\text { questionnaire }\end{array}$ & $\begin{array}{l}\text { Liver cancer incidence } \\
\text { Low } \\
\text { High } \\
\text { Met recommendations }\end{array}$ & $\begin{array}{l}1 \\
0.70(0.54,0.90) \\
0.60(0.41,1.01)\end{array}$ & Sex, and age \\
\hline $\begin{array}{l}\text { Baumeister (2019), } \\
\text { Multinational cohort study, } \\
10 \text { countries } \\
\text { (Denmark, France, } \\
\text { Germany, } \\
\text { Greece, Italy, } \\
\text { the Netherlands, } \\
\text { Norway, Spain, Sweden and } \\
\text { the United Kingdom) }\end{array}$ & $\begin{array}{l}467,336 \\
(1992-2000) \text {, mean } \\
\text { age } 51.3(9.9) \text { years }\end{array}$ & Mean: 14.9 years & $\begin{array}{l}\text { International } \\
\text { Classification of } \\
\text { Diseases-Oncology-2, HCC }\end{array}$ & $\begin{array}{l}\text { Physical activity } \\
\text { questionnaire }\end{array}$ & $\begin{array}{l}\text { Liver cancer incidence } \\
\text { Total physical activity } \\
\text { Inactive } \\
\text { Moderately Inactive } \\
\text { Moderately active } \\
\text { Active } \\
\text { Vigorous physical activity } \\
\text { None } \\
\leq 2 \mathrm{~h} / \text { week } \\
>2 \mathrm{~h} / \text { week }\end{array}$ & $\begin{array}{l}1 \\
0.65(0.48,0.89) \\
0.49(0.34,0.71) \\
0.55(0.38,0.80) \\
1 \\
0.50(0.33,0.75) \\
0.50(0.33,0.76)\end{array}$ & $\begin{array}{l}\text { Education, smoking } \\
\text { baseline alcohol } \\
\text { consumption, lifetime } \\
\text { alcohol, and coffee } \\
\text { intake }\end{array}$ \\
\hline $\begin{array}{l}\text { Behrens (2013), } \\
\text { the NIH-AARPDiet and } \\
\text { Health Study, } \\
\text { U.S.A. }\end{array}$ & $\begin{array}{l}4,604,015 \\
(1995-2006) \text {, mean } \\
\text { age } 62(5.4)\end{array}$ & Median: 9.1 years & $\begin{array}{l}\text { North American Association of } \\
\text { Central Cancer } \\
\text { Registries, and } \\
\text { International } \\
\text { Classification of Diseases for } \\
\text { Oncology (ICD-O-3) }\end{array}$ & $\begin{array}{l}\text { Physical activity } \\
\text { questionnaire }\end{array}$ & $\begin{array}{l}\text { Liver cancer incidence } \\
\text { Vigorous physical activity } \\
0 \\
<1 \\
1-2 \\
2-3 \\
5+\end{array}$ & $\begin{array}{l}1 \\
0.73(0.56,0.95) \\
0.70(0.56,0.88) \\
0.54(0.43,0.68) \\
0.45(0.35,0.58)\end{array}$ & Age and sex \\
\hline $\begin{array}{l}\text { Inoue (2008), the Japan } \\
\text { Public Health Center-based } \\
\text { Prospective Study, Japan }\end{array}$ & $\begin{array}{l}79,771 \\
(1995-1999), \text { aged } \\
45-74 \text { years }\end{array}$ & 7.5 years & $\begin{array}{l}\text { International Classification of } \\
\text { Diseases }\end{array}$ & $\begin{array}{l}\text { Physical activity } \\
\text { questionnaire }\end{array}$ & $\begin{array}{l}\text { Liver cancer incidence } \\
\text { Total physical activity } \\
\text { Man } \\
\text { Lowest } \\
\text { Second } \\
\text { Third } \\
\text { Highest } \\
\text { Women } \\
\text { Lowest } \\
\text { Second } \\
\text { Third } \\
\text { Highest }\end{array}$ & $\begin{array}{l}1 \\
0.69(0.45,1.06) \\
1.01(0.69,1.49) \\
0.62(0.40,0.96) \\
1 \\
0.96(0.52,1.78) \\
0.99(0.53,1.84) \\
0.54(0.23,1.29)\end{array}$ & $\begin{array}{l}\text { Age, total energy } \\
\text { intake, history of } \\
\text { diabetes, } \\
\text { smoking status, never } \\
\text { smoker, past smoker, } \\
\text { alcohol intake status, } \\
\text { body mass index } \\
\text { (BMI), } \\
\text { leisure-time sports or } \\
\text { physical exercise }\end{array}$ \\
\hline
\end{tabular}


Table 1. Cont

\begin{tabular}{|c|c|c|c|c|c|c|c|}
\hline $\begin{array}{l}\text { First Author (Year), Name } \\
\text { of Sudy, Country }\end{array}$ & $\begin{array}{c}\text { Sample Size } \\
\text { Study, } \\
\text { Recruitment } \\
\text { Period, and Age }\end{array}$ & $\begin{array}{l}\text { Follow-Up } \\
\text { Period (Year) }\end{array}$ & $\begin{array}{l}\text { Criteria of the } \\
\text { Cause of Death }\end{array}$ & $\begin{array}{c}\text { Exercise } \\
\text { Assessment }\end{array}$ & 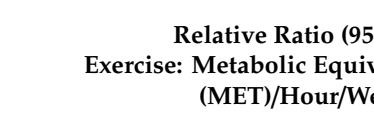 & $\begin{array}{l}\% \mathrm{CI}) \\
\text { alent of Task } \\
\text { ak }\end{array}$ & Adjusted for \\
\hline $\begin{array}{l}\text { Moore (2016), the Physical } \\
\text { Activity Collaboration of the } \\
\text { National Cancer Institute's } \\
\text { Cohort Consortium, U.S.A. }\end{array}$ & $\begin{array}{l}1,440,000 \\
(1987-2004), \\
\text { the median age } 59 \\
\text { years }\end{array}$ & A median 11 years & $\begin{array}{l}\text { The international } \\
\text { Classification of Diseases for } \\
\text { Oncology }\end{array}$ & $\begin{array}{l}\text { Physical activity } \\
\text { survey }\end{array}$ & $\begin{array}{l}\text { Liver cancer incidence } \\
\text { Leisure-time physical activity } \\
\text { Lower } \\
\text { Higher }\end{array}$ & $\begin{array}{l}1 \\
0.73(0.70,0.76)\end{array}$ & BMI \\
\hline $\begin{array}{l}\text { Simon (2019), the Nurses' } \\
\text { Health Study and the } \\
\text { Health Professionals } \\
\text { Follow-up Study, U.S.A. }\end{array}$ & $\begin{array}{l}125,264 \\
(1986-1989), \text { aged } \\
30-55 \text { years }\end{array}$ & 12 years & $\begin{array}{l}\text { National Death Index, } \\
\text { ICD-8, HCC }\end{array}$ & $\begin{array}{l}\text { Physical activity } \\
\text { questionnaire }\end{array}$ & $\begin{array}{l}\text { Liver cancer mortality } \\
\text { Lowest } \\
\text { Second } \\
\text { Third } \\
\text { Fourth } \\
\text { Highest }\end{array}$ & $\begin{array}{l}1 \\
0.70(0.51,0.96) \\
0.59(0.42,0.84) \\
0.52(0.36,0.74) \\
0.46(0.31,0.78)\end{array}$ & Age \\
\hline $\begin{array}{l}\text { Suzuki (2007), the Japan } \\
\text { Collaborative Cohort Study, } \\
\text { Japan }\end{array}$ & $\begin{array}{l}69,752(2005-2011) \\
\text { aged } 40-79 \text { years }\end{array}$ & 12 years & ICD-10 & $\begin{array}{l}\text { Physical activity } \\
\text { questionnaire }\end{array}$ & $\begin{array}{l}\text { Liver cancer mortality } \\
<1 \mathrm{~h} / \text { week } \\
>3 \mathrm{~h} / \text { week } \\
\text { Walking time (per day): men } \\
>1 \mathrm{~h} / \text { day } \\
0.5-1 \mathrm{~h} / \text { day } \\
<0.5 \mathrm{~h} / \text { day } \\
\text { Walking time (per day): women } \\
>1 \mathrm{~h} / \text { day } \\
0.5-1 \mathrm{~h} / \text { day } \\
<0.5 \mathrm{~h} / \text { day }\end{array}$ & $\begin{array}{l}1 \\
0.81(0.71,0.92) \\
1 \\
0.81(0.71,0.92) \\
1.43(1.10,1.86) \\
\\
1 \\
1.03(0.67,1.65) \\
1.84(1.27,2.66)\end{array}$ & Age, sex, area \\
\hline $\begin{array}{l}\text { Ukawa (2014), } \\
\text { the Japan Collaborative } \\
\text { Cohort Study, } \\
\text { Japan }\end{array}$ & $\begin{array}{l}\text { 69,752 (1998-1990), } \\
\text { aged 40-79 years }\end{array}$ & 19.4 years & $\begin{array}{l}\text { International } \\
\text { Classification of Diseases, Ninth } \\
\text { Revision, Clinical Modification }\end{array}$ & $\begin{array}{l}\text { Physical activity } \\
\text { questionnaire }\end{array}$ & $\begin{array}{l}\text { Liver cancer mortality } \\
\text { Walking time } \\
\text { Man and Women } \\
\leq 0.5 \mathrm{~h} / \text { day } \\
>0.5 \mathrm{~h} / \text { day } \\
\text { Man } \\
\leq 0.5 \mathrm{~h} / \text { day } \\
>0.5 \mathrm{~h} / \text { day } \\
\text { Women } \\
\leq 0.5 \mathrm{~h} / \text { day } \\
>0.5 \mathrm{~h} / \text { day }\end{array}$ & $\begin{array}{l}1 \\
0.77(0.59,0.99) \\
1 \\
0.81(0.58,1.14) \\
1 \\
0.70(0.47,1.07)\end{array}$ & $\begin{array}{l}\text { Age, sex, study area, } \\
\text { smoking status, } \\
\text { alcohol consumption, } \\
\text { daily consumption of } \\
\text { coffee, BMI, education } \\
\text { level, marital status, a } \\
\text { history of diabetes } \\
\text { mellitus, gall bladder } \\
\text { diseases, blood } \\
\text { transfusion }\end{array}$ \\
\hline
\end{tabular}


Table 1. Cont.

\begin{tabular}{|c|c|c|c|c|c|c|c|}
\hline $\begin{array}{l}\text { First Author (Year), Name } \\
\text { of Sudy, Country }\end{array}$ & $\begin{array}{c}\text { Sample Size } \\
\text { Study, } \\
\text { Recruitment } \\
\text { Period, and Age }\end{array}$ & $\begin{array}{l}\text { Follow-Up } \\
\text { Period (Year) }\end{array}$ & $\begin{array}{l}\text { Criteria of the } \\
\text { Cause of Death }\end{array}$ & $\begin{array}{l}\text { Exercise } \\
\text { Assessment }\end{array}$ & \multicolumn{2}{|c|}{$\begin{array}{l}\text { Relative Ratio }(95 \% \mathrm{CI}) \\
\text { Exercise: Metabolic Equivalent of Task } \\
\text { (MET)/Hour/Week }\end{array}$} & Adjusted for \\
\hline $\begin{array}{l}\text { Wen (2010), Health } \\
\text { Management Institution of } \\
\text { prospective cohort study, } \\
\text { Taiwan }\end{array}$ & $\begin{array}{l}416,175 \\
(1976-2007), \text { aged } \\
20-79 \text { years }\end{array}$ & 8.5 years & $\begin{array}{l}\text { National Death file and the } \\
\text { National Cancer } \\
\text { Registry file }\end{array}$ & $\begin{array}{l}\text { Physical activity } \\
\text { questionnaire }\end{array}$ & $\begin{array}{l}\text { Liver cancer mortality } \\
\text { Inactive } \\
\text { Low } \\
\text { Medium } \\
\text { High } \\
\text { Very high } \\
\text { Total } \\
\text { Liver cancer incidence } \\
\text { Inactive } \\
\text { Low } \\
\text { Medium } \\
\text { High } \\
\text { Very high } \\
\text { Total }\end{array}$ & $\begin{array}{l}1 \\
0.97(0.80,1.18) \\
0.92(0.75,1.12) \\
0.80(0.60,1.07) \\
0.65(0.49,0.86) \\
0.85(0.72,0.99) \\
1 \\
0.95(0.82,1.10) \\
0.85(0.73,1.00) \\
0.87(0.70,1.08) \\
0.70(0.56,0.86) \\
0.81(0.71,0.92)\end{array}$ & $\begin{array}{l}\text { Age, sex, education, } \\
\text { activity at work, } \\
\text { smoking, drinking, } \\
\text { fasting blood glucose, } \\
\text { systolic blood } \\
\text { pressure, BMI, } \\
\text { diabetes history, } \\
\text { hypertension, } \\
\text { history }\end{array}$ \\
\hline $\begin{array}{l}\text { Yun (2008), National Health } \\
\text { Insurance Corporation } \\
\text { Study, } \\
\text { Republic of Korea }\end{array}$ & $\begin{array}{l}444,963 \\
(1996-2002) \text { mean } \\
\text { age } 49(6.5) \\
\text { years old }\end{array}$ & 6 years & Korean Central Cancer Registry & $\begin{array}{l}\text { Physical activity } \\
\text { questionnaire }\end{array}$ & $\begin{array}{l}\text { Liver cancer incidence } \\
\text { Low } \\
\text { Moderate to high }\end{array}$ & $\begin{array}{l}1 \\
0.85(0.79,0.92)\end{array}$ & Age \\
\hline
\end{tabular}




\section{Results}

The selection processes for this meta-analysis are detailed in Figure 1. A total of 18,376 studies were found in an initial search. From this total, 18,333 studies were excluded based on title and abstract screening. The full texts of the remaining 43 studies were reviewed, and 33 studies that did not report an RR or HR for associations between physical activity and risks and mortality of liver cancer were excluded. Finally, 10 studies that met the criteria for this meta-analysis were selected [18-27].

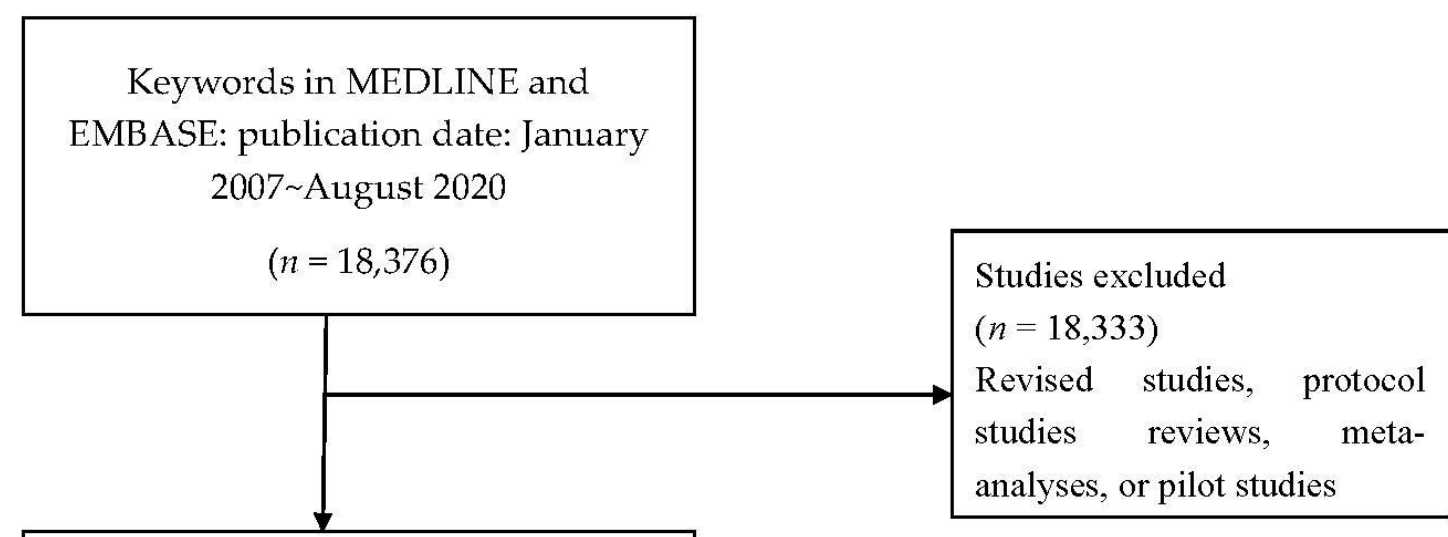

Potentially relevant studies retrieved

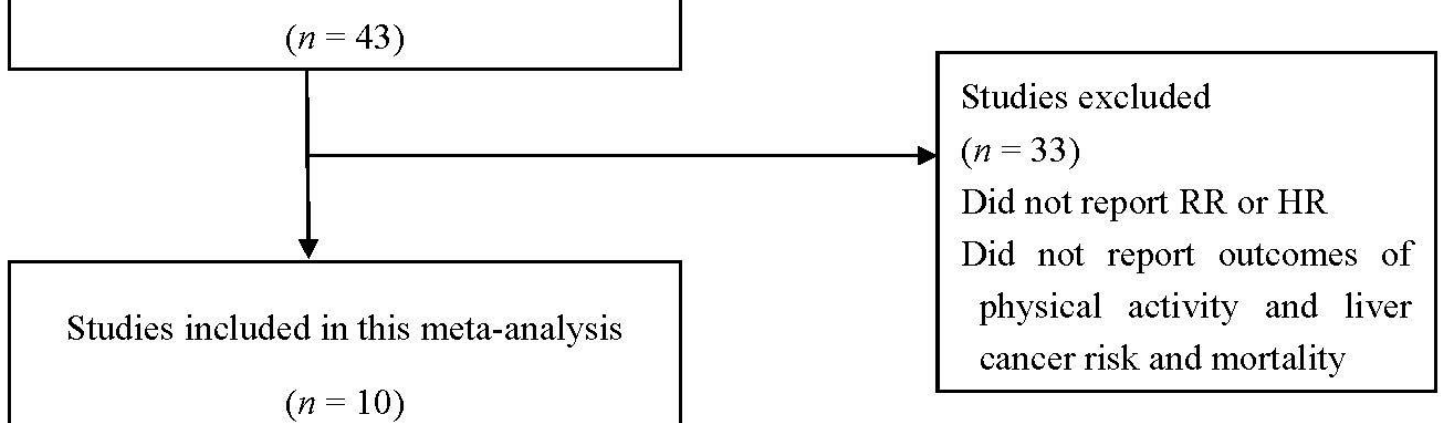

Figure 1. Selection process for the systematic review and meta-analysis.

Ten prospective cohort studies presented in Table 1. Four studies were conducted in the United States of America. One multi-nation study included subjects in Denmark, France, Germany, Greece, Italy, the Netherlands, Norway, Spain, Sweden, and the United Kingdom. Three studies were performed in Japan, one study was conducted in Taiwan, and one study was performed in the Republic of Korea. Physical activity was measured by physical activity questionnaires. In total, 8,283,426 subjects are included in this meta-analysis. An average follow-up was 11.35 years and ranged from 6 to 19.4 years. The amount of physical activity was pooled from each study, which indicated whether the amount was high, moderate, or low. A high amount of physical activity was defined as an average of $\geq 3 \mathrm{~h}$ per week, a moderate amount of physical activity as 2 to $3 \mathrm{~h}$ per week, and a low amount of physical activity as $<2 \mathrm{~h}$ per week.

\subsection{Associations between Physical Activity and Liver Cancer Risks}

High and moderate amounts of physical activity were associated with a $75 \%$ decreased risk of liver cancer $(0.75(95 \% \mathrm{CI}, 0.72-0.77 ; p=0.001))$ compared to low amounts of physical activity in fourteen studies (Figure 2). Subgroup analyses categorized by high and moderate amounts of physical activity were conducted. Eight trials were included to analyze the association between a high amount of physical activity and liver cancer risks. Individuals who participated in high amounts of physical 
activity had lower liver cancer risks compared to those who participated in low amounts of physical activity $(0.74(95 \% \mathrm{CI}, 0.72-0.77 ; p=0.001))$. The association between a moderate amount of physical activity and liver cancer risk was computed based on six studies. A moderate amount of physical activity was associated with lower cancer risk compared to those who participated in low amounts of physical activity $(0.77(95 \% \mathrm{CI}, 0.69-0.86 ; p=0.001))$. Statistically significant heterogeneity across sampled studies was found, based on the association between high and moderate amounts of physical activity and liver cancer risks. No publication bias or any apparent influence of unpublished data were detected by using the trim and fill method.

\begin{tabular}{lcccrr} 
Study name & \multicolumn{5}{c}{ Statistics for each study } \\
& $\begin{array}{c}\text { Hazard } \\
\text { ratio }\end{array}$ & $\begin{array}{c}\text { Lower } \\
\text { limit }\end{array}$ & $\begin{array}{c}\text { Upper } \\
\text { limit }\end{array}$ & Z-Value & p-Value \\
Arem, 2017 high & 0.70 & 0.54 & 0.90 & -2.74 & 0.01 \\
Arem, 2017 moderate & 0.60 & 0.38 & 0.94 & -2.21 & 0.03 \\
Baumeister, 2019 high & 0.55 & 0.38 & 0.80 & -3.15 & 0.00 \\
Baumeister, 2019 moderate & 0.49 & 0.34 & 0.71 & -3.80 & 0.00 \\
Behrens, 2013 high & 0.45 & 0.35 & 0.58 & -6.20 & 0.00 \\
Benhrens, 2013 moderate & 0.70 & 0.56 & 0.88 & -3.09 & 0.00 \\
Inoue, 2008 high men & 0.62 & 0.40 & 0.96 & -2.14 & 0.03 \\
Inoue, 2008 high women & 0.54 & 0.23 & 1.28 & -1.40 & 0.16 \\
Inoue, 2008 moderate men & 1.01 & 0.69 & 1.48 & 0.05 & 0.96 \\
Inoue, 2008 moderate women & 0.99 & 0.53 & 1.84 & -0.03 & 0.97 \\
Moore, 2016 high & 0.73 & 0.70 & 0.76 & -15.00 & 0.00 \\
Wen, 2010 high & 0.70 & 0.56 & 0.87 & -3.26 & 0.00 \\
Wen, 2010 moderate & 0.85 & 0.73 & 0.99 & -2.09 & 0.04 \\
Yun, 2008 high & 0.85 & 0.79 & 0.92 & -4.18 & 0.00 \\
& 0.75 & 0.72 & 0.77 & -17.45 & 0.00
\end{tabular}

Test for heterogeneity: $\left(\mathrm{Q}=44.34, \mathrm{P}=0.00, \mathrm{I}^{2}=70.68 \%\right)$

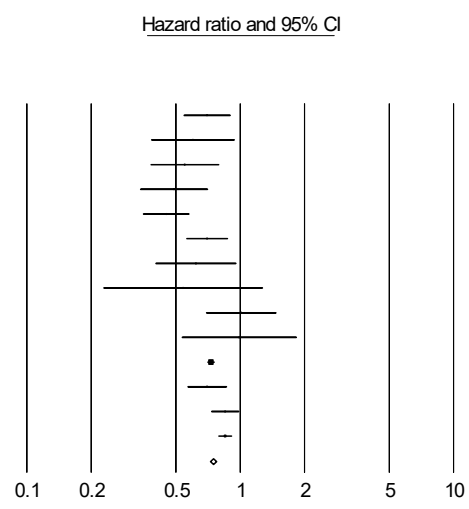

High and moderate amount of physical activity and liver cancer risks

\begin{tabular}{lcccrr} 
Study name & \multicolumn{5}{c}{ Statistics for each study } \\
& $\begin{array}{c}\text { Hazard } \\
\text { ratio }\end{array}$ & $\begin{array}{c}\text { Lower } \\
\text { limit }\end{array}$ & $\begin{array}{c}\text { Upper } \\
\text { limit }\end{array}$ & Z-Value & p-Value \\
Arem, 2017 & 0.70 & 0.54 & 0.90 & -2.74 & 0.01 \\
Baumeister, 2019 & 0.55 & 0.38 & 0.80 & -3.15 & 0.00 \\
Behrens, 2013 & 0.45 & 0.35 & 0.58 & -6.20 & 0.00 \\
Inoue, 2008 men & 0.62 & 0.40 & 0.96 & -2.14 & 0.03 \\
Inoue, 2008 women & 0.54 & 0.23 & 1.28 & -1.40 & 0.16 \\
Moore, 2016 & 0.73 & 0.70 & 0.76 & -15.00 & 0.00 \\
Wen, 2010 & 0.70 & 0.56 & 0.87 & -3.26 & 0.00 \\
Yun, 2008 & 0.85 & 0.79 & 0.92 & -4.18 & 0.00 \\
& 0.74 & 0.72 & 0.77 & -16.84 & 0.00
\end{tabular}

Test for heterogeneity: $\left(\mathrm{Q}=32.03 .69, \mathrm{P}=0.00, \mathrm{I}^{2}=78.15 \%\right)$

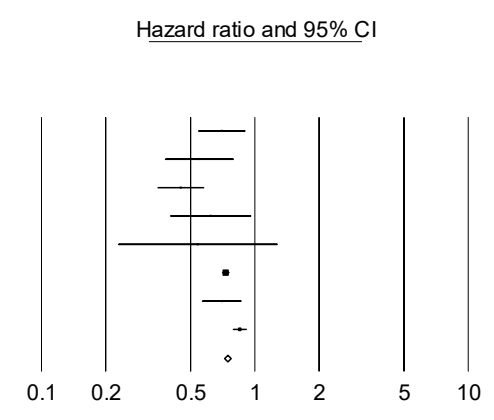

Subgroup analysis: High amount of physical activity and liver cancer risks

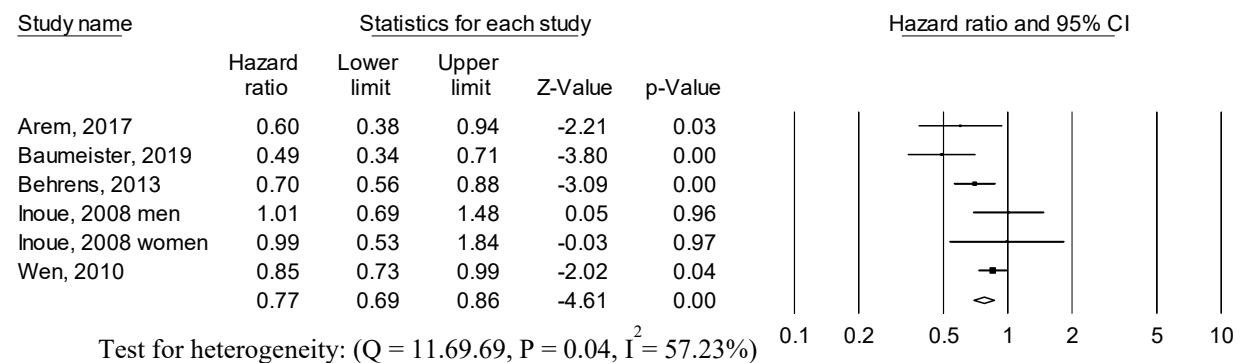

Subgroup analysis: Moderate amount of physical activity and liver cancer incidence

Figure 2. Physical activity and liver cancer risks. 


\subsection{Associations between Vigorous Intensity and Amount of Physical Activity and Liver Cancer Risk}

Four studies reported that vigorous intensity and high and moderate amounts of physical activity were associated with a $56 \%$ decreased risk of liver cancer ( 0.56 (95\% CI, $0.48-0.64 ; p=0.001)$ ) compared to vigorous intensity and low amounts of physical activity (Figure 3). Subgroup analyses were conducted by the amount of vigorous intensity physical activity regimens. In two studies, vigorous intensity and high amounts of physical activity were associated with a $44 \%$ lower risk of liver cancer $(0.46(95 \%$ CI, $0.37-0.57 ; p=0.001)$ ) than vigorous intensity and low amounts of physical activity. In addition, in two studies, vigorous intensity and moderate amounts of physical activity were associated with a $35 \%$ lower risk of liver cancer $(0.65(95 \% \mathrm{CI}, 0.53-0.79 ; p=0.001))$ than vigorous intensity and low amounts of physical activity. No statistically significant heterogeneity across the sampled studies was detected in the vigorous intensity and both the high and moderate amounts of physical activity and liver cancer risk studies. The trim and fill method revealed no publication bias or any apparent influence of unpublished data.

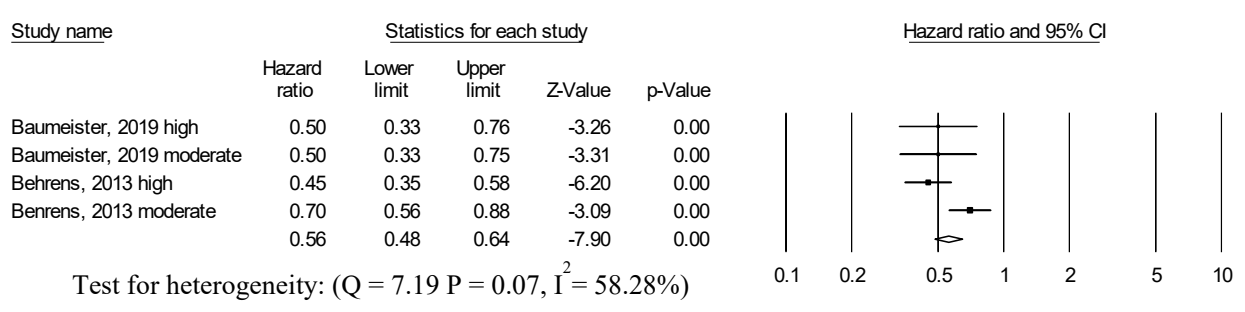

\section{Vigorous intensity and high and moderate amount of physical activity and liver cancer risks}

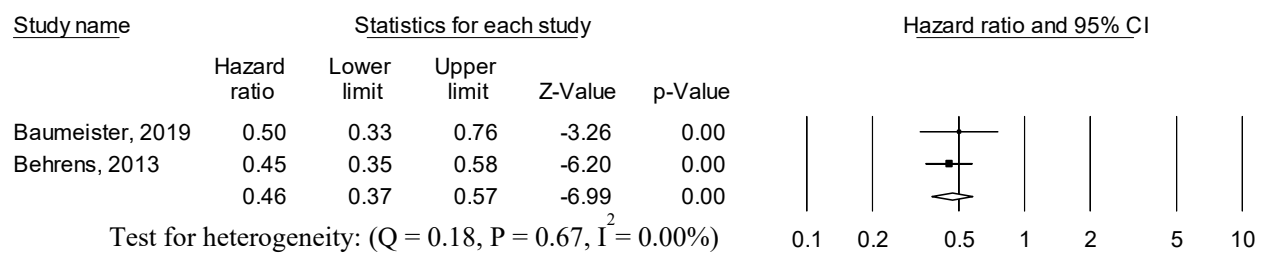

Subgroup analysis: Vigorous intensity and high amount of physical activity and liver cancer risks

\begin{tabular}{lcccrr} 
Study name & \multicolumn{5}{c}{ Statistics for each study } \\
& $\begin{array}{c}\text { Hazard } \\
\text { ratio }\end{array}$ & $\begin{array}{c}\text { Lower } \\
\text { limit }\end{array}$ & $\begin{array}{c}\text { Upper } \\
\text { limit }\end{array}$ & Z-Value & p-Value \\
Baumeister, 2019 & 0.50 & 0.33 & 0.75 & -3.31 & 0.00 \\
Behrens, 2013 & 0.70 & 0.56 & 0.88 & -3.09 & 0.00 \\
& 0.65 & 0.53 & 0.79 & -4.31 & 0.00
\end{tabular}

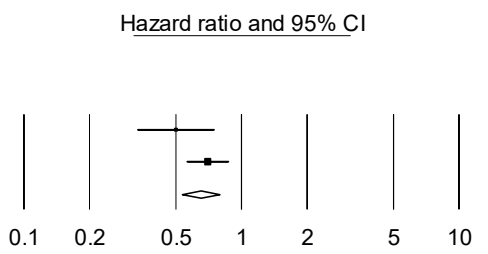

Test for heterogeneity: $\left(\mathrm{Q}=1.98, \mathrm{P}=0.16, \mathrm{I}^{2}=49.51 \%\right)$

Subgroup analysis: Vigorous intensity and moderate amount of physical activity and liver cancer risks

Figure 3. Vigorous intensity and moderate amount of physical activity, and liver cancer risks. 


\subsection{Associations between Physical Activity and Liver Cancer Mortality}

Eight studies reported that participating in high and moderate physical activity was associated with a $78 \%$ decreased risk of liver cancer mortality $(0.78(95 \% \mathrm{CI}, 0.73-0.84 ; p=0.001))$ compared to low amounts of physical activity (Figure 4). Participants with high amounts of physical activity had a $25 \%$ reduced liver cancer mortality compared to participants with low amounts of physical activity $(0.75(95 \%$ CI, $0.67-0.83 ; p=0.001))$ in four studies. Moderate physical activity was associated with a $19 \%$ decrease in liver cancer mortality $(0.81(95 \%$ CI, $0.73-0.89 ; p=0.001))$ in four studies. Statistically significant heterogeneity across sampled studies was found in the association between high amounts of physical activity and liver cancer mortality, but no heterogeneity across sampled studies was found in the association between moderate amounts of physical activity and liver cancer mortality. There was no publication bias or any apparent influence of unpublished data based on the trim and fill method.

\begin{tabular}{lccccr} 
Study name & \multicolumn{5}{c}{ Statistics for each study } \\
& $\begin{array}{c}\text { Hazard } \\
\text { ratio }\end{array}$ & $\begin{array}{c}\text { Lower } \\
\text { limit }\end{array}$ & $\begin{array}{c}\text { Upper } \\
\text { limit }\end{array}$ & Z-Value & p-Value \\
Simon, 2019 high & 0.46 & 0.32 & 0.67 & -4.03 & 0.00 \\
Simon, 2019 moderate & 0.59 & 0.42 & 0.83 & -3.04 & 0.00 \\
Suzuki, 2007 high & 0.81 & 0.71 & 0.92 & -3.19 & 0.00 \\
Suzuki, 2007 moderate & 0.81 & 0.71 & 0.92 & -3.19 & 0.00 \\
Ukawa, 2014 high & 0.77 & 0.59 & 1.00 & -1.98 & 0.05 \\
Ukawa, 2014 moderate & 0.77 & 0.59 & 1.00 & -1.94 & 0.05 \\
Wen, 2010 high & 0.65 & 0.49 & 0.86 & -3.00 & 0.00 \\
Wen, 2010 moderate & 0.92 & 0.75 & 1.12 & -0.82 & 0.42 \\
& 0.78 & 0.73 & 0.84 & -6.94 & 0.00 \\
\multicolumn{1}{c}{ Test for heterogeneity: $\left(\mathrm{Q}=14.97, \mathrm{P}=0.04, \mathrm{I}^{2}=53.25 \%\right)$}
\end{tabular}

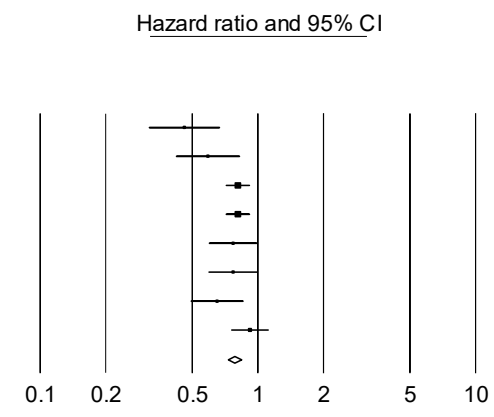

High and moderate amount of physical activity and liver cancer mortality

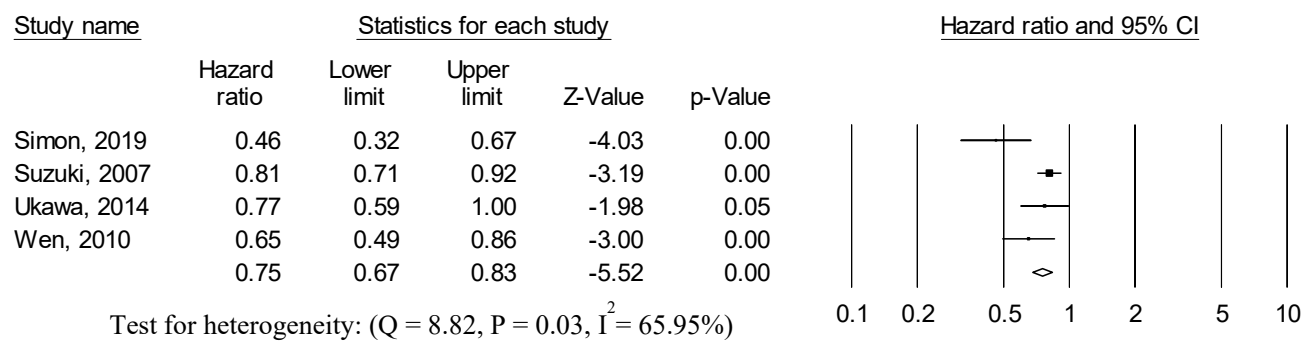

Subgroup analysis: High amount of physical activity and liver cancer mortality

\begin{tabular}{|c|c|c|c|c|c|c|c|c|c|c|}
\hline \multirow[t]{2}{*}{ Study name } & \multicolumn{5}{|c|}{ Statistics for each study } & & \multicolumn{4}{|c|}{ Hazard ratio and $95 \% \mathrm{Cl}$} \\
\hline & $\begin{array}{c}\text { Hazard } \\
\text { ratio }\end{array}$ & $\begin{array}{c}\text { Lower } \\
\text { limit }\end{array}$ & $\begin{array}{c}\text { Upper } \\
\text { limit }\end{array}$ & Z-Value & $\mathrm{p}$-Value & & & & & \\
\hline Simon, 2019 & 0.59 & 0.42 & 0.83 & -2.98 & 0.00 & & & & & \\
\hline Suzuki, 2007 & 0.81 & 0.71 & 0.92 & -3.19 & 0.00 & & & & $=$ & \\
\hline Ukawa, 2014 & 0.77 & 0.59 & 1.00 & -1.98 & 0.05 & & & & - & \\
\hline \multirow[t]{2}{*}{ Wen, 2010} & 0.92 & 0.75 & 1.12 & -0.82 & 0.42 & & & & $\rightarrow$ & \\
\hline & 0.81 & 0.73 & 0.89 & -4.33 & 0.00 & & & & $\diamond$ & \\
\hline Test fo & terooen & $\mathrm{O}=4$ & $P=0$ & $I^{2}=38$ & & 0.1 & 0.2 & 0.5 & 1 & 2 \\
\hline
\end{tabular}

\section{Subgroup analysis: Moderate amount of physical activity and liver cancer} mortality

Figure 4. Physical activity, and liver cancer mortality. 


\section{Discussion}

Risks and mortality of liver cancer were associated with the amount and intensity of physical activity. High ( $\geq 3 \mathrm{~h}$ per week) and moderate amounts ( 2 to $3 \mathrm{~h}$ per week) of physical activity were associated with lower risks and mortality of liver cancer compared to low amounts ( $<2 \mathrm{~h}$ per week) of physical activity. Considering the exercise intensity, the selected studies in this meta-analysis only reported associations between vigorous intensity and high, moderate, and low amounts of physical activity and risks of liver cancer. Physical inactivity was associated with increased liver cancer mortality. More than $2 \mathrm{~h}$ per week of physical activity, which was more than the low amount of physical activity $(<2 \mathrm{~h}$ per week) used as a reference, may help reduce the risk and mortality associated with liver cancer.

Participating in physical activity had an inverse association with liver cancer risks. Depending on the amount of physical activity, high amounts of physical activity were associated with a $26 \%$ decreased risk of liver cancer. In addition, a moderate amount of physical activity was associated with a $23 \%$ decreased risk of liver cancer. These findings are in agreement with previous meta-analyses $[12,16,28]$. The type of physical activity such as leisure-time physical activity and walking was not specified in this meta-analysis because of the limited number of selected studies; therefore, evaluation of specific types of activity are needed in future studies. The associations between high and moderate amounts of physical activity and liver cancer risks had statistically significant heterogeneity across sampled studies in this meta-analysis; therefore, these values could be associated with types and intensities of physical activity. Analysis of physical activity intensity in this meta-analysis did not allow for comparison with other intensities, specifically moderate intensity and low intensity physical activity because studies only reported vigorous intensity with high, moderate, and low amounts of physical activity. More than $2 \mathrm{~h}$ per week of physical activity was congruent with a recent study that recommended at least $2.1 \mathrm{~h}$ per week of leisure-time physical activity as well as suggested that there are inverse relationships between physical activity intensity and liver cancer risk [13]. A sensitivity analysis of vigorous intensity indicated that individuals who engaged in high amounts of physical activity had a $54 \%$ decreased risk of liver cancer and subjects that did moderate amounts of physical activity had a 35\% decreased risk of liver cancer compared to low amounts of physical activity. Vigorous intensity and high amounts of physical activity were associated with the lowest risk of liver cancer in this meta-analysis. There was no statistically significant heterogeneity across sampled studies in vigorous intensity and high and moderate amounts of physical activity, although the analyses were only conducted for vigorous intensity.

Liver cancer mortality was decreased by $22 \%$ in individuals who performed high and moderate amounts of physical activity, by $25 \%$ in individuals who performed high amounts of physical activity, and by $19 \%$ in participants who performed moderate amounts of physical activity. Reduced liver cancer mortality in this current meta-analysis was similar to a previous meta-analysis that conducted a sensitivity analysis of three studies that reported a $20 \%$ decrease in liver cancer mortality in individuals performing high amounts of physical activity compared to low amounts of physical activity [16]. A previous meta-analysis reported that reduced all-cause mortality was associated with participation in high amounts of physical activity [12]. Additionally, a previous study reported reduced liver cancer mortality in those who performed at least 90 min per week of physical activity [26], and pre-diagnosis moderate to vigorous intensity leisure-time physical activity was associated with a $29 \%$ reduced risk of liver cancer mortality [29]. The current findings for the associations between physical activity and liver cancer mortality do not consider intensity and type of physical activity; therefore, those results may be associated with statistically significant heterogeneity across sampled studies. Although liver cancer mortality was decreased by participating in high and moderate amounts of physical activity, additional studies that consider the type and intensity of physical activity are needed to confirm these findings.

There are several possible mechanisms for the beneficial effects of physical activity on liver cancer risks and mortality. First, physical activity leads to decreased hyperglycemia, which may be associated with reduced growth-promoting and mitogenic activity of cancer cells and carcinogenesis by increasing insulin-like growth factor [30-32]. In addition, decreased insulin resistance can lead to 
lower levels of proinflammatory cytokines, including tumor necrosis factor-alpha, interleukin-6, leptin, and chronic hepatic inflammatory markers, which have been associated with liver diseases including liver cancer [33-36]. Third, the beneficial effects of physical activity include decreased adiposity, including visceral adipose tissue volume, which has been associated with the progression of fibrosis, inflammation, and liver fat [37]. Finally, increased physical activity may improve circulation, immune function, energy balance, and insulin sensitivity, which influence and can reduce the associated risks of liver cancer $[5,23,25]$.

This meta-analysis was strengthened by the dose-dependent analyses of the amount of time of physical activities that were included in prospective cohort studies, and by considering the intensity of physical activity. However, there are several limitations to this meta-analysis. First, although the populations of the selected studies were large, the total number of selected studies for this meta-analysis was only 10; therefore, generalizations are limited. Second, the findings of this meta-analysis do not support the causality of the associations between physical activity and liver cancer risks and associated mortality; therefore, the findings should be considered carefully. Third, physical activity was measured using self-reported questionnaires. More objective measurements including accelerometers should be used in future studies. In addition, physical activities including walking, leisure-time activities, and other activities should be specified to assess the impact of specific types of activity. Fourth, the RR or HR for each study in selected studies was adjusted for different factors such as age and sex, which could influence the associations in this meta-analysis. Finally, time points for measuring physical activity were evaluated prior to a diagnosis of liver cancer; therefore, there is a possibility that the physical activity patterns could change after the liver cancer diagnosis.

\section{Conclusions}

In this meta-analysis, participating in physical activity had beneficial effects including reduced risk and death in liver cancer patients. Considering physical activity intensity, type, and amount, additional studies need to confirm these findings. Recommendations for liver cancer patients suggest that regular physical activity for more than $2 \mathrm{~h}$ per week may be a minimum physical activity level that can help reduce liver cancer risks and mortality. Even for vigorous physical activity intensity, high amounts of physical activity, which showed the lowest mortality values for liver cancer compared with moderate and low amounts of physical activity, may be more favorable than moderate and low amounts of physical activity for preventing liver cancer risks. Although more studies need to be conducted, guidelines for participating in physical activity for more than $2 \mathrm{~h}$ per week at vigorous intensity may help improve patient outcomes.

Funding: This research received no external funding.

Conflicts of Interest: The author declares no conflict of interest.

\section{References}

1. WHO. Obesity and Oberweight. Available online: https://www.who.int/en/news-room/fact-sheets/detail/ obesity-and-overweight (accessed on 29 August 2020).

2. Tapper, E.B.; Parikh, N.D. Mortality due to cirrhosis and liver cancer in the United States, 1999-2016: Observational study. BMJ 2018, 362, k2817. [CrossRef] [PubMed]

3. Jemal, A.; Ward, E.M.; Johnson, C.J.; Cronin, K.A.; Ma, J.; Ryerson, B.; Mariotto, A.; Lake, A.J.; Wilson, R.; Sherman, R.L.; et al. Annual Report to the Nation on the Status of Cancer, 1975-2014, Featuring Survival. J. Natl. Cancer Inst. 2017, 109. [CrossRef]

4. Ryerson, A.B.; Eheman, C.R.; Altekruse, S.F.; Ward, J.W.; Jemal, A.; Sherman, R.L.; Henley, S.J.; Holtzman, D.; Lake, A.; Noone, A.M.; et al. Annual Report to the Nation on the Status of Cancer, 1975-2012, featuring the increasing incidence of liver cancer. Cancer 2016, 122, 1312-1337. [CrossRef]

5. Berzigotti, A.; Saran, U.; Dufour, J.F. Physical activity and liver diseases. Hepatology 2016, 63, 1026-1040. [CrossRef] 
6. Kruk, J.; Czerniak, U. Physical activity and its relation to cancer risk: Updating the evidence. Asian Pac. J. Cancer Prev. 2013, 14, 3993-4003. [CrossRef]

7. van der Windt, D.J.; Sud, V.; Zhang, H.; Tsung, A.; Huang, H. The Effects of Physical Exercise on Fatty Liver Disease. Gene Expr. 2018, 18, 89-101. [CrossRef]

8. Lee, J. A Meta-analysis of the Association Between Physical Activity and Breast Cancer Mortality. Cancer Nurs. 2019, 42, 271-285. [CrossRef]

9. Moorman, P.G.; Jones, L.W.; Akushevich, L.; Schildkraut, J.M. Recreational physical activity and ovarian cancer risk and survival. Ann. Epidemiol. 2011, 21, 178-187. [CrossRef]

10. Schmid, D.; Leitzmann, M.F. Association between physical activity and mortality among breast cancer and colorectal cancer survivors: A systematic review and meta-analysis. Ann. Oncol. 2014, 25, 1293-1311. [CrossRef]

11. Orsini, N.; Bellocco, R.; Bottai, M.; Pagano, M.; Andersson, S.O.; Johansson, J.E.; Giovannucci, E.; Wolk, A. A prospective study of lifetime physical activity and prostate cancer incidence and mortality. Br. J. Cancer 2009, 101, 1932-1938. [CrossRef]

12. Li, Y.; Gu, M.; Jing, F.; Cai, S.; Bao, C.; Wang, J.; Jin, M.; Chen, K. Association between physical activity and all cancer mortality: Dose-response meta-analysis of cohort studies. Int. J. Cancer 2016, 138, 818-832. [CrossRef]

13. Matthews, C.E.; Moore, S.C.; Arem, H.; Cook, M.B.; Trabert, B.; Hakansson, N.; Larsson, S.C.; Wolk, A.; Gapstur, S.M.; Lynch, B.M.; et al. Amount and Intensity of Leisure-Time Physical Activity and Lower Cancer Risk. J. Clin. Oncol. 2020, 38, 686-697. [CrossRef]

14. O’Donovan, G.; Lee, I.M.; Hamer, M.; Stamatakis, E. Association of "Weekend Warrior" and Other Leisure Time Physical Activity Patterns With Risks for All-Cause, Cardiovascular Disease, and Cancer Mortality. JAMA Intern. Med. 2017, 177, 335-342. [CrossRef]

15. Lin, Z.Z.; Xu, Y.C.; Liu, C.X.; Lu, X.L.; Wen, F.Y. Physical Activity and Liver Cancer Risk: A Systematic Review and Meta-analyses. Clin. J. Sport Med. 2018. [CrossRef]

16. Baumeister, S.E.; Leitzmann, M.F.; Linseisen, J.; Schlesinger, S. Physical Activity and the Risk of Liver Cancer: A Systematic Review and Meta-Analysis of Prospective Studies and a Bias Analysis. J. Natl. Cancer Inst. 2019, 111, 1142-1151. [CrossRef] [PubMed]

17. Liberati, A.; Altman, D.G.; Tetzlaff, J.; Mulrow, C.; Gotzsche, P.C.; Ioannidis, J.P.; Clarke, M.; Devereaux, P.J.; Kleijnen, J.; Moher, D. The PRISMA statement for reporting systematic reviews and meta-analyses of studies that evaluate health care interventions: Explanation and elaboration. J. Clin. Epidemiol. 2009, 62, e1-e34. [CrossRef]

18. Inoue, M.; Yamamoto, S.; Kurahashi, N.; Iwasaki, M.; Sasazuki, S.; Tsugane, S.; Japan Public Health Center-Based Prospective Study Group. Daily total physical activity level and total cancer risk in men and women: Results from a large-scale population-based cohort study in Japan. Am. J. Epidemiol. 2008, 168, 391-403. [CrossRef] [PubMed]

19. Moore, S.C.; Lee, I.M.; Weiderpass, E.; Campbell, P.T.; Sampson, J.N.; Kitahara, C.M.; Keadle, S.K.; Arem, H.; Berrington de Gonzalez, A.; Hartge, P.; et al. Association of Leisure-Time Physical Activity With Risk of 26 Types of Cancer in 1.44 Million Adults. JAMA Intern. Med. 2016, 176, 816-825. [CrossRef] [PubMed]

20. Suzuki, K. Japan Collaborative Cohort Study for Evaluation of, C. Health conditions and mortality in the Japan Collaborative Cohort Study for Evaluation of Cancer (JACC). Asian Pac. J. Cancer Prev. 2007, 8, $25-34$.

21. Ukawa, S.; Tamakoshi, A.; Wakai, K.; Kurozawa, Y. Associations of daily walking and television viewing time with liver cancer mortality: Findings from the Japan Collaborative Cohort Study. Cancer Causes Control 2014, 25, 787-793. [CrossRef]

22. Behrens, G.; Matthews, C.E.; Moore, S.C.; Freedman, N.D.; McGlynn, K.A.; Everhart, J.E.; Hollenbeck, A.R.; Leitzmann, M.F. The association between frequency of vigorous physical activity and hepatobiliary cancers in the NIH-AARP Diet and Health Study. Eur. J. Epidemiol. 2013, 28, 55-66. [CrossRef] [PubMed]

23. Baumeister, S.E.; Schlesinger, S.; Aleksandrova, K.; Jochem, C.; Jenab, M.; Gunter, M.J.; Overvad, K.; Tjonneland, A.; Boutron-Ruault, M.C.; Carbonnel, F.; et al. Association between physical activity and risk of hepatobiliary cancers: A multinational cohort study. J. Hepatol. 2019, 70, 885-892. [CrossRef]

24. Arem, H.; Loftfield, E.; Saint-Maurice, P.F.; Freedman, N.D.; Matthews, C.E. Physical activity across the lifespan and liver cancer incidence in the NIH-AARP Diet and Health Study cohort. Cancer Med. 2018, 7, 1450-1457. [CrossRef] [PubMed] 
25. Simon, T.G.; Kim, M.N.; Luo, X.; Yang, W.; Ma, Y.; Chong, D.Q.; Fuchs, C.S.; Meyerhardt, J.A.; Corey, K.E.; Chung, R.T.; et al. Physical activity compared to adiposity and risk of liver-related mortality: Results from two prospective, nationwide cohorts. J. Hepatol. 2020, 72, 1062-1069. [CrossRef]

26. Wen, C.P.; Wai, J.P.; Tsai, M.K.; Yang, Y.C.; Cheng, T.Y.; Lee, M.C.; Chan, H.T.; Tsao, C.K.; Tsai, S.P.; Wu, X. Minimum amount of physical activity for reduced mortality and extended life expectancy: A prospective cohort study. Lancet 2011, 378, 1244-1253. [CrossRef]

27. Yun, Y.H.; Lim, M.K.; Won, Y.J.; Park, S.M.; Chang, Y.J.; Oh, S.W.; Shin, S.A. Dietary preference, physical activity, and cancer risk in men: National health insurance corporation study. BMC Cancer 2008, 8, 366. [CrossRef] [PubMed]

28. Duncan, K.; Harris, S.; Ardies, C.M. Running exercise may reduce risk for lung and liver cancer by inducing activity of antioxidant and phase II enzymes. Cancer Lett. 1997, 116, 151-158. [CrossRef]

29. Arem, H.; Moore, S.C.; Park, Y.; Ballard-Barbash, R.; Hollenbeck, A.; Leitzmann, M.; Matthews, C.E. Physical activity and cancer-specific mortality in the NIH-AARP Diet and Health Study cohort. Int. J. Cancer 2014, 135, 423-431. [CrossRef]

30. Tandon, P.; Ismond, K.P.; Riess, K.; Duarte-Rojo, A.; Al-Judaibi, B.; Dunn, M.A.; Holman, J.; Howes, N.; Haykowsky, M.J.F.; Josbeno, D.A.; et al. Exercise in cirrhosis: Translating evidence and experience to practice. J. Hepatol. 2018, 69, 1164-1177. [CrossRef]

31. Giovannucci, E.; Harlan, D.M.; Archer, M.C.; Bergenstal, R.M.; Gapstur, S.M.; Habel, L.A.; Pollak, M.; Regensteiner, J.G.; Yee, D. Diabetes and cancer: A consensus report. Diabetes Care 2010, 33, 1674-1685. [CrossRef]

32. Donatto, F.F.; Neves, R.X.; Rosa, F.O.; Camargo, R.G.; Ribeiro, H.; Matos-Neto, E.M.; Seelaender, M. Resistance exercise modulates lipid plasma profile and cytokine content in the adipose tissue of tumour-bearing rats. Cytokine 2013, 61, 426-432. [CrossRef] [PubMed]

33. Chen, Z.; Yu, R.; Xiong, Y.; Du, F.; Zhu, S. A vicious circle between insulin resistance and inflammation in nonalcoholic fatty liver disease. Lipids Health Dis. 2017, 16, 203. [CrossRef] [PubMed]

34. Leclercq, I.A.; Da Silva Morais, A.; Schroyen, B.; Van Hul, N.; Geerts, A. Insulin resistance in hepatocytes and sinusoidal liver cells: Mechanisms and consequences. J. Hepatol. 2007, 47, 142-156. [CrossRef] [PubMed]

35. Kerr, J.; Anderson, C.; Lippman, S.M. Physical activity, sedentary behaviour, diet, and cancer: An update and emerging new evidence. Lancet Oncol. 2017, 18, e457-e471. [CrossRef]

36. Pillon Barcelos, R.; Freire Royes, L.F.; Gonzalez-Gallego, J.; Bresciani, G. Oxidative stress and inflammation: Liver responses and adaptations to acute and regular exercise. Free Radic. Res. 2017, 51, 222-236. [CrossRef]

37. Lira, F.S.; Rosa, J.C.; Zanchi, N.E.; Yamashita, A.S.; Lopes, R.D.; Lopes, A.C.; Batista, M.L., Jr.; Seelaender, M. Regulation of inflammation in the adipose tissue in cancer cachexia: Effect of exercise. Cell Biochem. Funct. 2009, 27, 71-75. [CrossRef] [PubMed]

Publisher's Note: MDPI stays neutral with regard to jurisdictional claims in published maps and institutional affiliations.

(C) 2020 by the author. Licensee MDPI, Basel, Switzerland. This article is an open access article distributed under the terms and conditions of the Creative Commons Attribution (CC BY) license (http://creativecommons.org/licenses/by/4.0/). 